Pobrane z czasopisma Annales I - Philosophy and Sociology http://philosophia.annales.umcs.pl Data: 26/04/2023 13:55:37

DOI: $10.17951 / i .2018 .43 .2 .93-105$

A N N A L E S

UNIVERSITATIS MARIAE CURIE-SKŁODOWSKA

LUBLIN - POLONIA

VOL. XLIII, 2

SECTIO I

2018

\author{
CEZARY MORDKA \\ ORCID: 0000-0001-8254-6565 \\ Uniwersytet Marii Curie-Skłodowskiej w Lublinie
}

\title{
Realistyczna interpretacja domniemanego idealizmu G. Berkeleya
}

Realistic Interpretation of Alleged G. Berkeley’s Idealism

\section{WPROWADZENIE}

Analiza poglądów G. Berkeleya, poza czysto historycznymi względami, nie wydaje się mieć dzisiaj wielkiego sensu. Filozof, który stwierdza w pierwszym artykule swego Traktatu o zasadach poznania ludzkiego, iż jedynymi przedmiotami ludzkiej wiedzy są idee zmysłowe, refleksyjne, pamięci i wyobraźni - a wszystkie one istnieją w umyśle ${ }^{1}$ - sytuuje się na antypodach dominującego dziś naturalizmu.

Nawet pobieżny przegląd współczesnych prac dotyczących teorii umysłu (m.in. D. Denneta, J. Kima, F. Dretskego, teoretyków komputacyjnej teorii umysłu czy zdecydowanych redukcjonistów, jak wczesny R. Rorty, D. Armstrong czy P.M. Churchland) pokazuje przepaść między poglądami siedemnastowiecznego filozofa a materialistycznymi tendencjami tak mocno obecnymi w dzisiejszych filozofiach umysłu i człowieka.

Wielu teoretyków sądzi wręcz, że już wkrótce (to sprawa skądinąd fascynującego rozwoju neuronauki) nasze potoczne przekonania dotyczące bólu, pragnień, doznań czy myśli okażą się przejawem umysłowej ignorancji dokładnie w takim samym sensie, jak sądy o czarownicach, demonach czy flogistonie. R. Rorty znamiennie wskazuje faktyczny desygnat wypowiedzi na temat bólu:

1 G. Berkeley, Traktat o zasadach poznania ludzkiego, Warszawa 1956, s. 58. 
Wasze słowa były konstatacją wystąpienia pewnego procesu mózgowego, więc uprości to nam życie, jeśli zamiast „czuję ból” będziecie mówić „mam pobudzone C-neurony” - i prima facie sytuacja nauki wydaje się tu tak samo dobra, jak gdy na pytanie szamana „Czego konstatacją były moje słowa o demonach” odpowiadamy „Konstatowałeś omamy halucynacyjne, więc uprości to nam życie, jeśli od dzisiaj takie przeżycia przedstawiał będziesz w taki właśnie sposób"2.

Fundamentalne zagadnienie istnienia realnego świata „poza umysłem”, będące konsekwencją Berkeleyowskiego myślenia w kartezjańskiej tradycji, zostało nie tyle rozstrzygnięte, co pominięte i pozostawione - po prostu wyszło z użycia. Mimo to warto poświęcić więcej niż chwilę na czysto historyczną refleksję nad pismami irlandzkiego filozofa.

Zasadniczym powodem wydaje się radykalny charakter eksploracji filozoficznych, które prędzej czy później stawiają przed rozważaniem propozycji tradycyjnie przypisywanej Berkeleyowi. Tę tradycyjną interpretację wraz z uwagami krytycznymi przedstawiam w pierwszej części artykułu, drugą zaś poświęcam pewnym wątkom w pismach Berkeleya, które - jak sądzę - umożliwiają opowiedzenie się za relacjonistyczno-realistycznym ujęciem jego poglądów.

Warto pamiętać, że Berkeley zgubił manuskrypt drugiej (z trzech planowanych) części swego Traktatu o zasadach poznania ludzkiego, unikał też wyraźnych odpowiedzi na pytania skądinąd życzliwie doń nastawionych krytyków, co z pewnością nie ułatwia rekonstrukcji jego poglądów.

\section{IDEALIZM SUBIEKTYWNY. ARGUMENTACJA}

Argumentacja Berkeleya za punkt wyjścia przyjmuje krytykę ontologii Locke'owskiej z jej założeniem wielości skończonych umysłów, jednego nieskończonego, idei w umysłach i rzeczy fizycznych. Istnienie tych ostatnich pozostaje na gruncie teorii Locke'a zupełnie niesprawdzalne, a nawet niezrozumiałe. Co więcej, jak uważa Berkeley, bezpośrednio nieznane rzeczy musiałyby być przyczynami idei, co zdaje się niemożliwe, zważywszy na bierność i bezwładność materii ${ }^{3}$.

Berkeley, odróżniając rzeczy realne od urojeń, stwierdza więc, iż zarówno jedne, jak i drugie są w równej mierze ideami, tkwią w umyśle, istnieją, o ile są postrzegane. Owe idee były interpretowane jako ,zjawiska psychiczne”

2 R. Rorty, Identyczność ciała i umystu, [w:] Filozofia umystu, wyb. B. Chwedeńczuk, Warszawa 1995, s. 221.

3 C.W.K. Mundle, Perception: Facts and Theories, Lodon 1971, s. 64. 
Pobrane z czasopisma Annales I - Philosophy and Sociology http://philosophia.annales.umcs.pl Data: 26/04/2023 13:55:37

(K. Ajdukiewicz ${ }^{4}$, ,zespoły wrażeń zmysłowych” (R. Ingarden $\left.{ }^{5}\right)$, modi czy to „podmiotu”, czy „świadomości umysłu” (M. Whiton Calkins $\left.{ }^{6}\right)$.

Przypisywanie rzeczom istnienia „poza spostrzeżeniem” według Berkeleya jest jednym z przypadków akceptacji „idei abstrakcyjnych”. W jego rozumieniu są to byty, które mogłyby istnieć niezależnie od percipi. Byty niezależne od postrzegania są jednak niepoznawalne, a przyjęcie istnienia przedmiotu niepoznawalnego jest według Berkeleya sprzecznością. „Trzeba tylko, abyście zajrzeli do własnych myśli i spróbowali, czy jesteście w stanie pojąć, że dźwięk czy kształt, ruch czy barwa mogłyby istnieć poza umysłem"”.

Wydaje się to bardzo proste, ponieważ łatwo można wyobrazić sobie drzewa rosnące w miejscowym parku, a przy tym nikogo, kto by je postrzegał. Jednak, pisze Berkeley, ten brak postrzegającego zakłada milcząco obecność podmiotu rozważającego nieistnienie samego postrzegającego. „Pozbycie się” owego podmiotu okazuje się niemożliwe, a postrzeganie świata bez podmiotu niepojęte ${ }^{8}$. Berkeley zaprzecza więc istnieniu przedmiotu, o którym nie można pomyśleć.

W dalszym ciągu argumentacji filozof przypisuje ideom bycie jedyną rzeczywistością, wraz z brakiem ich podobieństwa do przedmiotów materialnych. Gdyby bowiem idee były kopiami rzeczy materialnych, to owe rzeczy same musiałyby być ideami, gdyż idee mogą być podobne tylko do idei ${ }^{9}$. Faktycznie, jeśli nie mamy dostępu do niczego innego niż idee, to trudno mówić o relacji podobieństwa do rzeczywistości. Pojawia się przy tym zasadnicze pytanie: Czy wszystko, z czym mamy do czynienia, to własne idee?

W § 8-14 Traktatu napotykamy argumentację Berkeleya zwalczającego pogląd Locke'a, jakoby istniały rzeczy materialne mające jakości pierwszorzędne, niebędące ideami, a zarazem podobne do niektórych naszych idei. Według niego, jeśli jakości drugorzędne są subiektywne (są ideami), to i jakości pierwszorzędne muszą być takie, nie sposób bowiem rozdzielić obu tych typów.

Chciałbym jednak, by każdy zastanowił się i spróbował, czy dzięki jakiejkolwiek abstrakcji zdoła przedstawić sobie rozciągłość i ruch ciała bez wszelkich innych jakości zmysłowych. Co do mnie, widzę wyraźnie, że nie potrafiłbym utworzyć idei ciała rozciągłego i poruszającego się, któ-

\footnotetext{
4 K. Ajdukiewicz, Epistemologia i semiotyka, [w:] Język i poznanie, t. 2, Warszawa 1985, s. 110.

5 R. Ingarden, Niektóre założenia idealizmu Berkeleya, [w:] Księga Pamiątkowa Polskiego Towarzystwa Filozoficznego, Lwów 1931, s. 15.

6 M. Whiton Calkins (ed.), Berkeley, Essays, Principles, Dialogues With Selections from Other Writings, New York 1929.

7 G. Berkeley, Traktat o zasadach..., s. 49-50.

8 Ibidem, s. 50.

9 Ibidem, s. 40. Według R. Ingardena (op. cit., s. 30) Berkeley nie uzasadnił tego twierdzenia.
} 
remu bym nie musiał zarazem przypisać jakiejś barwy lub innej jakości zmysłowej, która, jak się przyznaje, istnieje tylko w umyśle ${ }^{10}$.

Oprócz związku jakości pierwotnych i wtórnych Berkeley wskazuje na fakt zmienności percypowania rzeczy w zależności od stanu narządów zmysłowych czy - szerzej-zmienności podmiotowej ${ }^{11}$. Tak jest w przypadku wielkości czegoś czy jego smaku ${ }^{12}$.

Według R. Ingardena napotykamy tu ważną argumentację natury epistemologicznej ${ }^{13}$. Jeśli cokolwiek występuje w pewnym spostrzeżeniu jako cecha $a$ (np. słodkość) przedmiotu $P$, a następnie przechodzi w innym spostrzeżeniu tego samego $P$, spełnianym przez ten sam podmiot, w pewne $b$ (np. gorzkość) jedynie dzięki temu, że zmieniły się subiektywne warunki spostrzegania, a nie zmienił się przedmiot $P$, to ani $a$, ani $b$ nie przysługuje przedmiotowi $P$, lecz jest jedynie jego ,ideą".

Wbrew Berkeleyowi jednak sam brak przysługiwania nie musi mieć konsekwencji w postaci uznania czegoś za „tylko subiektywne” (w terminologii Berkeleya za ideę „w umyśle”). Co więcej, jeśli przyznać, iż dany przedmiot zmienia się co do danej własności (rzekomo subiektywnej), to czy nie trzeba założyć, że on sam nie jest tylko zestawem idei, ale czymś od nich różnym, „tym samym” mimo zmienności?

Najważniejsze jednak jest, że Berkeley powołuje się na fakt przejścia pewnej cechy „a” w cechę „b” przy niezmiennym przedmiocie (rzeczy spostrzeganej), a więc i to niezmienianie się jest faktem dla niego, i to faktem, którego przyjęcie jest niezbędne dla przeprowadzenia jego argumentacji. Inaczej nie miałby powodu uważać cech „a” i „b” za „relatywne”, za tylko „w duchu” istniejące. Jeżeliby faktem dla niego było tylko to, że ilekroć „a” przechodzi w „b”, nie ma niczego niezmieniającego się, lecz mamy tylko szereg różnych pomiędzy sobą idei, nie byłoby powodu dla uważania pewnych cech za względne, za „tylko subiektywne” [podkr. - C.M.]. Wówczas wszystkie elementy idej byłyby na jednym poziomie i nie byłoby argumentu przeciw „materialistom”, bo w tym wypadku można by równie dobrze stanąć na stanowisku naiwnego realizmu (można by wszystkie elementy rzeczy spostrzeganych uważać za cechy przedmiotom materialnym przysługujące), jak i na stanowisku idealistycznym (a więc znów wszystkie cechy rzeczy spostrzeganych, a z nimi i same rzeczy, uważać za „tylko subiektywne” idee) $)^{14}$.

Berkeley pisze o zmianach w „narządach zmysłowych”, lecz zakłada (co jest niekonsekwencją), iż można same te zmiany stwierdzić oraz stwierdzić własności

10 G. Berkeley, Traktat o zasadach..., s. 41-42.

11 Ibidem, s. 42.

12 A.A. Luce, T.E. Jessop (eds.), The Works of George Berkeley, Bishop of Cloyne, Vol. 2, Lodon 1949, s. 163.

13 R. Ingarden, op. cit., s. 34.

14 Ibidem, s. 42. 
Pobrane z czasopisma Annales I - Philosophy and Sociology http://philosophia.annales.umcs.pl Data: 26/04/2023 13:55:37

od modyfikacji w narządach zmysłowych. O tym, że akceptuje on pogląd idealistyczny, przesądza jego (po prostu) przyjęta teoria spostrzeżenia wraz z koncepcją formalnej budowy przedmiotu. Idąc dalej, Berkeley sprowadza spostrzeżenie i przedmiot spostrzeżony do sfery doznań zmysłowych biernie przez podmiot posiadanych ${ }^{15}$, stając przed problemem tożsamości przedmiotu, który jako taki jest spostrzegany. W § 1 Traktatu twierdzi, iż zbiory wrażeń powtarzają się, co skłania nas do nazwania takich zbiorów jednym wyrazem i dopiero tożsamość nazwy nadaje im jedność wraz z ową tożsamością. Jednocześnie odrzuca pojęcie substancji jako substratu cech, wikłając się w kolejną trudność, ponieważ sama nazwa jako brzmienie to także idea, której tożsamość domaga się następnej (i tak w nieskończoność) nazwy. Redukując świat do zbioru idei o mentalnym charakterze, musi również odpowiedzieć na pytanie o podmiot owych idei.

Jak wiadomo, Berkeley postuluje istnienie wielu podmiotów (duchów), które nie mają charakteru idei. Jak jednak te podmioty wzajemnie się poznają?

Rozwiązaniem Berkeleya jest wprowadzenie kategorii notion w drugim wydaniu Traktatu. Posiadać notion czegoś, co nie jest przedmiotem zmysłowym, to znaczy posiadać wiedzę niezmysłową, znać coś, rozumieć sens słowa oznaczającego (np. ducha, władzę, operację lub stan umysłu) oraz wszelkiego rodzaju stosunki między ideami ${ }^{16}$.

Berkeley unika widma solipsyzmu za pomocą wątpliwej analogii: tak jak idee, które znajdują się w innych umysłach, poznajemy za pomocą naszych własnych idei (np. ideę ciepła czy niebieskości), tak też poznajemy inne duchy za pomocą własnej duszy ${ }^{17}$.

Podsumowując, należy stwierdzić, że argumentacja Berkeleya, mająca rzekomo prowadzić do idealizmu subiektywnego, zawodzi w wielu punktach:

1. Uznanie niemożliwości istnienia przedmiotu całkowicie niepoznawalnego ,ze sprzeczności pomyślenia czegoś, o czym nic nie wiemy", jest ewidentnie fałszywa. Nie sposób wprawdzie poznać coś niepoznawalnego czy pojąć to, co niepojmowalne, lecz nie ma sprzeczności w pojęciu istnienia rzeczy, których się nie pojmuje ${ }^{18}$.

2. Argumentacja wskazująca na „subiektywność” świata zewnętrznego zakłada ów świat (w przypadku przyjęcia narządów zmysłowych, czyli ciała ludzkie-

15 Por. G.E. Moore, The Refutation of Idealism, [w:] Philosophical Studies, London 1951, s. 34.

16 M. Hempoliński, U źródel filozofii zdrowego rozsądku, Warszawa 1966, s. 23.

17 G. Berkeley, Traktat o zasadach..., § 140, 145, 148.

18 „Nie można myśleć o świecie, który nie jest myślany, gdy myślimy o rzeczy samej w sobie, staje się ona przedmiotem myśli, a zatem pojęcie rzeczy samej w sobie, rzeczy, która nie jest przedmiotem myśli, jest wewnętrznie sprzeczne. Argument ten jest nie do obalenia, ponieważ jest tautologią" - L. Kołakowski, Husserl i poszukiwanie pewności, Warszawa 1991, s. 70. 
go) oraz przedmiot, którego cechy mają być następnie uznawane za subiektywne, jako niesubiektywny, błędnie wreszcie przypisuje „subiektywność” cech na podstawie „rozmaitości spostrzeżeń” (jeśli coś percypuję raz jako gorzkie, a innym razem jako słodkie, to wynika z tego co najwyżej, że mylę się co do uznania jednej z tych cech, mylę się co do uznania ich obu, lecz nie prowadzi to do wniosku o ich subiektywnym wytwarzaniu).

3. Berkeley, „subiektywizując” świat, nie potrafi uporać się z problemem jego tożsamości, ucieka się do przyjęcia nazw na oznaczenie kompleksów idei nazw, których tożsamość sama musi być wątpliwa.

4. Oceniając z zewnątrz teorię Berkeleya, należy zwrócić uwagę na przeoczenie momentu intencjonalnego zawartego $\mathrm{w}$ akcie spostrzegania. Uwaga filozofa jest skierowana na doznawanie przedmiotów, lecz nie wykazał on, iż doznawana własność jest z zasady subiektywna.

5. Stanowisko irlandzkiego filozofa zdaje się przy takich sformułowaniach prowadzić do solipsyzmu, choć w tradycyjnej interpretacji jego pism trwałość świata jest gwarantowana przez Boga.

Koncepcja Boga jako gwaranta stałości świata prowadzi do poważnych trudności, musiałby on bowiem stale percypować nieskończoną ilość danych dotyczących jakiegokolwiek bytu, w każdej jego modalności i perspektywie (Berkeley, jak wiadomo, odrzucał istnienie idei abstrakcyjnych). Być może omnipotencja Boga pozwala na to, lecz opór budzi konieczność percepcji przez immaterialny byt wszelkich wrażeń cielesnych, łącznie np. z erotycznymi.

Takie implikacje, jak sądzi C.W.K. Mudle ${ }^{19}$, skłoniły Berkeleya do uznania, iż Bóg doświadcza rodzajów ,archetypów”, choć stoi to w sprzeczności ze wspomnianym odrzuceniem idei abstrakcyjnych. Niezależnie jednak od tego rozstrzygnięcia Berkeley nie twierdził, iż doświadczamy boskich idei, a jedynie własnych, co prowadzi do dalszych (niewyjaśnionych przez niego) problemów.

\section{INTERPRETACJA REALISTYCZNO-RELACJONISTYCZNA}

Przedstawiony powyżej zarys tradycyjnej interpretacji pozostaje niezgodny z wieloma wątkami, jakie znajdujemy w pismach Berkeleya. Wnikliwa analiza jego tekstów, przeprowadzona zwłaszcza przez H. Elzenberga ${ }^{20}$, A.A. Luce ${ }^{21}$,

19 C.W.K. Mundle, op. cit., s. 67.

20 H. Elzenberg, Domniemany immanentyzm Berkeleya, [w:] I. Dąmbska (red.), Szkice filozoficzne. Romanowi Ingardenowi w darze, Warszawa 1964, s. 25-48.

21 A.A. Luce, The Dialectic of Immaterialism, London 1963; idem, Berkeley's Immaterialism, London 1950. 
F.J.E. Woodbridge'a ${ }^{22}$ czy S. Kijaczko ${ }^{23}$, pozwala na nieco inne rozumienie poglądów filozofa.

Przede wszystkim trudno zgodzić się z twierdzeniami interpretującymi dokonania Berkeleya w duchu subiektywizmu, w duchu redukcji tzw. świata zewnętrznego do treści immanentnych podmiotowi ${ }^{24}$. W jego pismach uderza liczba wypowiedzi stwierdzających rzeczywistość świata zewnętrznego: $[\ldots]^{25}$.

Nie przeczymy temu, że idee wrażone w zmysły są rzeczami realnymi, czyli realnie istnieją

Nie chcę zmieniać rzeczy na idee, lecz raczej idee na rzeczy, ponieważ uważam za same rzeczy realne te bezpośrednie przedmioty postrzegania, które dla ciebie są tylko pozorami rzeczy ${ }^{26}$.

Berkeley pisze o pewności i rzeczywistości tego, co widzimy, czego dotykamy czy słyszymy, o rzeczywistości, która jawnie różni się od tego, co urojone ${ }^{27}$. Doskonale odróżnia też akt postrzegającego umysłu od czegoś, co jest postrzega$\mathrm{ne}^{28}$, nie podając w wątpliwość rzeczy, które istnieją realnie, które widzimy i dotykamy $^{29}$. Z dezaprobatą wspomina o filozofach odmawiających rzeczywistości przyrodzie, przesądzających, iż jest ona tylko „złudną grą wyobraźni” ${ }^{30}$. Berkeley twierdzi, iż zupełnie zgodne z jego poglądami jest przekonanie o realności rzeczy, o istnieniu ciał, ,jeśli bierze się to $\mathrm{w}$ pospolitym rozumieniu [...]"31.

Niepodobna, według tego filozfa, myśleć o domach, rzekach, górach czy drzewach tak, jak o tworach (złudzeniach) wyobraźni ${ }^{32}$. To, co spostrzegamy, przekonuje, jest rzeczywiste, jest pewne, a w szczególności nie ma sensu podważać różnicy między urojeniami a rzeczywistością. „Słońce, które widzę za dnia, jest słońcem rzeczywistym, to zaś, które sobie wyobrażam nocą, jest ideą tamtego"33.

22 F.J.E. Woodbridge, Berkeley's Realism, [w:] Studies in the History of Ideas, Vol. 1, Cambridge 1918, s. 212.

23 S. Kijaczko, Miejsce i rola empirystycznej teorii poznania $w$ systemie filozofii immaterialistycznej Berkeleya, Lublin 1991 (niepublikowany doktorat, UMCS).

24 Przed przypisywaniem Berkeleyowi dziwacznych z punktu widzenia zdrowego rozsądku twierdzeń typu ,jemy i pijemy idee" ostrzega C.M. Turbayne.

25 G. Berkeley, Traktat o zasadach..., s. 90.

26 Idem, Trzy dialogi między Hylasem i Filonusem, Warszawa 1956, s. 287.

27 Idem, Traktat o zasadach..., s. 58.

28 Idem, Trzy dialogi..., s. 20.

29 Idem, Traktat o zasadach..., s. 47, 58, 61; idem, Trzy dialogi..., s. 261.

${ }^{30}$ Idem, Trzy dialogi..., s. 230.

31 Idem, Traktat o zasadach..., s. 92.

32 G. Berkeley wyraźnie odróżnia doznania zmysłowe od wyobrażeń. Por. A. Guzzo, Berkeley and “Things", [w:] W.E. Steinkraus (ed.), New Studies in Berkeley's Philosophy, New York 1966, s. 73.

33 G. Berkeley, Traktat o zasadach..., s. 58. 
Berkeley, co znamienne, chce uchodzić za filozofa zdrowego rozsądku. Podstawowym celem jego immaterializmu miał być właśnie powrót do natury i przekonań zdroworozsądkowych ${ }^{34}$. Według mnie „momentem rozruchowym” jego filozofii był atak i sprzeciw wobec werbalnych spekulacji, zawiłych, niemających odniesienia do doświadczenia i samego życia abstrakcji scholastyków, a przede wszystkim (jego teologiczne nastawienie miało tu zasadnicze znaczenie) pojęciu materii ${ }^{35}$.

[...] godzi przede wszystkim w „metafizyczny” materializm, z jego naczelną kategorią czy zasadą materii, jako niepoznawalnego substratum, zawierającego w sobie wszystko inne jako własne atrybuty, istniejącego absolutnie, bez początku i końca, niebędącego wyrazem niczego, co by je poprzedziło ${ }^{36}$.

Według Berkeleya skoro substancja materialna nie pozostaje w żadnej relacji do doświadczenia, przestaje tym samym być nazwą dla czegokolwiek ${ }^{37}$. Zauważa ponadto, że poza „względnym pojęciem materii jako podłoża akcydensów lub jakości, jej definicja jest złożona z samych zaprzeczeń”. A skoro tak, nie ma ona żadnej treści albo zawiera treść niedorzeczną ${ }^{38}$. Materialne substratum Locke'a oraz materia prima Arystotelesa to „czcze nazwy” oraz „mętne i nieokreślone abstrakcje" 39 . W parze z krytyką materii idzie zaprzeczenie sensu mówienia o „absolutnym istnieniu rzeczy niemyślących”, czyli przedmiotów zmysłowych samych w sobie.

Uzasadnione jest natomiast badanie rzeczy jakoś znanych, nas dotyczących, a ma to miejsce oczywiście dopiero wtedy, gdy są one (jakoś) postrzegane ${ }^{40}$. Te rzeczy to idee, czyli dane w doświadczeniu byty, które „czujemy, widzimy i poznajemy zmysłami” ${ }^{41}$. Idea nie jest czymś psychicznym lub - szerzej - pod-

34 Idem, Trzy dialogi..., s. 159, 164, 165.

35 Por. A.A. Luce, Berkeley's New Principle Completed, [w:] E. Steinkraus (ed.), New Studies in Berkeley's Philosophy, New York 1967, s. 10.

36 S. Kijaczko, op. cit., s. 31.

37 Wielu krytyków zarzuca Berkeleyowi niekonsekwencję, która polega na tym, iż odrzucając materię, pozostawił realność ducha, choć powody odrzucenia dają się zastosować do obu tych „przedmiotów”. Zob. np. A.J. Ayer, Language, Truth and Logic, New York 1936, s. 54. Podobne uwagi czynili C.D. Broad czy P. Coffey.

${ }_{38}$ G. Berkeley, Trzy dialogi..., s. 256.

39 „Jeśli zbadamy, co filozofowie, przestrzegający największej ścisłości, sami oświadczają, że rozumieją przez substancję materialną, to napotykamy na ich twierdzenie, że nie przywiązują do tych dźwięków żadnego innego znaczenia poza ideą bytu w ogóle, w połączeniu ze względnym pojęciem podtrzymywania przezeń akcydensów. [...] Ale czyż twiedzenie takie nie jest czymś po prostu sprzecznym i całkowicie niepojętym?”- idem, Traktat o zasadach ..., art. 1.

40 Idem, Trzy dialogi..., s. 318.

${ }^{41}$ Ibidem, s. 261. 
Pobrane z czasopisma Annales I - Philosophy and Sociology http://philosophia.annales.umcs.pl Data: 26/04/2023 13:55:37

miotowym, co wydaje się jasne, zważywszy na odróżnienie i oddzielenie przez Berkeleya podmiotów (duchów) i idei ${ }^{42}$. Duchy bowiem i idee są „bardzo różne”, „odmienne”, „nie mają nic wspólnego" ${ }^{43}$.

Berkeley dzieli wszystkie byty na świadome (myślące) i nieświadome ${ }^{44} . \mathrm{Te}$ świadome to duchy (spirits), nieświadome zaś to „rzeczy” (things). Stosuje on także określenie „rzeczy” w najogólniejszym sensie, stosowanym w odniesieniu do duchów. Wtedy pojawia się podział na rzeczy myślące (thinking things) i rzeczy niemyślące (unthinking things) ${ }^{45}$. Rzeczy myślące to duchy, natomiast to, co w pierwszym podziale było rzeczami, Berkeley często określa jako idee. W § 139 idee odróżnione są od ducha czy duszy jako „niemyślące przedmioty”. Berkeley waha się, raz określając ideę jako rzecz, a raz jako rzecz niemyślącą, lecz za każdym razem utrzymuje termin ,idea" ${ }^{46}$. Czemu jednak pozostaje przy tak niejasnym terminie, jak ,idea”, i jaką ma ona cechę pozytywną?

Otóż dla Berkeleya cechą charakterystyczną „rzeczy niemyślącej” jest bycie postrzeżoną. Idee, czyli rzeczy „niemyślące”, są „rzeczami postrzeżonymi”, a duchy to „rzeczy myślące i postrzegające”. Skoro jednak idee i duchy (łącznie z Bogiem) różnią się, powstaje pytanie, dlaczego Berkeley sytuuje idee „W umyśle"?

Odróżniając rzeczy realne od urojeń lub idei utworzonych przez nas samych, twierdzi wszak, że ,wszelako zarówno jedne, jak i drugie istnieją w umyśle, i w tym znaczeniu w równiej mierze są ideami [podkr. - C.M.]" ${ }^{\prime 4}$. Berkeley zdawał sobie sprawę z możliwości błędnego rozumienia tak często powtarzanego przez niego określenia „być w umyśle”. Pisał, iż chciałby uniknąć dosłownego znaczenia tego zwrotu, nadając mu sens ujmowania rzeczy przez umysł, wraz z ich doznawaniem ${ }^{48}$. Przekonywał o powszechności użycia przez filozofów sformułowań mówiących o bezpośrednich przedmiotach poznania jako o istniejących w umyśle, bez uznania, iż są one tam naprawdę. (W Dialogu III, 250 Hylas pyta Filonusa: „Are you not guitly of some abuse of language in this?”. Filonus odpowiada: ,[...] nothing is being more usual, than for philosophers to speak of the immediate objects of the understanding as things existing in mind"49).

42 Idem, Traktat o zasadach..., s. 53, 98, 139.

43 Ibidem, s. 36, 53.

44 I.C. Tipton (Berkeley's View of Spirit, [w:] W.E. Steinkraus (ed.), New Studies in Berkeley's Philosophy, New York 1962) dokonał szczegółowej analizy zagadnienia podmiotu w pismach Berkeleya.

${ }^{45}$ H. Elzenberg, op. cit., s. 44.

46 Ibidem, s. 45.

47 G. Berkeley, Traktat o zasadach..., s. 58.

48 Idem, Trzy dialogi..., s. 296.

49 Cyt. za: H. Elzenberg, op. cit., s. 41. 
Sposób mówienia jest „zapożyczony” w świecie przedmiotów zmysłowych, stąd gdy mowa o umyśle, naturalne wydaje się stosowanie „grubych” znaczeń, których nie sposób brać dosłownie ${ }^{50}$. Rację ma więc H. Elzenberg, gdy sądzi, iż „być w umyśle” to dla Berkeleya „być postrzeganym” czy „ujmowanym” przez umys $^{51}$ :

C.M. Turbayne twierdzi po prostu, że „in the mind” to „martwa przenośnia”, która w ówczesnej angielszczyźnie „,znalazła się wygodnie pod ręką̧”; Luce zaś powołuje się na kilka tekstów (Phil. Comm. 802, Princ. 3, Dial. I, 175, Dial III, 236), by wykazać, że „,in the mind” jest zwrotem skrótowym zamiast pełnego „in relation to the mind”, bo byłoby zbyt „niezręczne dla bieżącego użytku". Poza tym zwraca Luce jeszcze uwagę, że po angielsku doskonale można powiedzieć, iż „Muzeum Brytyjskie jest w moim umyśle” w chwili, gdy o nim myślę, albo że „Góry Dublińskie są in my sight $\mathrm{z}$ okien mojego gabinetu ${ }^{52}$.

Z kolei S. Kijaczko ${ }^{53}$ zwraca uwagę na to, iż w takich sformułowaniach, jak to bear in the mind oraz to keep in the mind podkreśla się przytomność i uwagę umysłu, a także jego wzgląd na daną rzecz. Określenie in the mind oznacza u Berkeleya „w zasięgu umysłu” (tak jak in the sight - „w zasięgu wzroku”), a out of the mind - ,poza zasięgiem umysłu” (jak out of the sight - „poza zasięgiem wzroku").

Według A. Hochfeldowej Berkeley uniknąłby wielu nieporozumień, zachowując wobec nie-boskich umysłów zwrot „dla umysłu” i pozostawiając „, umyśle" na oznaczenie sposobu istnienia idei w stosunku do Boga ${ }^{54}$. Podobne uwagi odnotował E.A. Sillem ${ }^{55}$.

Zatem sformułowanie „w umyśle” oznacza „dla umysłu” i jest związane $\mathrm{z}$ bezsensownością mówienia nie tyle o tym, co nieznane, ile o zasadniczej niepoznawalności. Istnieje bowiem, jak wskazuje Berkeley, wciąż nieodkryty, „niezmierzony obszar świata", stanowiący część postrzeganego przez nas układu kosmicznego ${ }^{56}$. Rzeczy są więc ideami, czyli jestestwami niemającymi absolutnego charakteru, o nie-podmiotowym charakterze, dane skończonemu umysłowi w ich

50 H. Elzenberg powołuje się na Trzy dialogi między Hylasem i Filonusem. Według The Works of George Berkeley, Bishop of Cloyne (op. cit.): „When I speak of objects as existnig in the mind, [...] my meaning is only that the mind comprehends or perceives them" - Dial III, 250, za: H. Elzenberg, op. cit., s. 40.

${ }_{51}$ H. Elzenberg, op. cit., s. 40.

52 Ibidem, s. 42.

53 S. Kijaczko, op. cit., s. 184.

54 A. Hochfeldowa, Kryzys teologii naturalnej: George Berkeley, „Archiwum Historii Filozofii i Myśli Społecznej” 1971, t. 17, s. 190.

55 E.A. Sillem, George Berkeley and the Proofs for the Existence of Good, London 1957, s. 139 i nast.

56 G. Berkeley, Trzy dialogi..., s. 228. 
Pobrane z czasopisma Annales I - Philosophy and Sociology http://philosophia.annales.umcs.pl Data: 26/04/2023 13:55:37

Realistyczna interpretacja domniemanego idealizmu G. Berkeleya

103

koniecznym z nim związku ${ }^{57}$. Problem stanowi pytanie, o jaki umysł chodzi i na czym polega ten konieczny związek.

Berkeley wpierw mówi o aktualnym postrzeganiu ${ }^{58}$ przez umysł rzeczy jako o warunku ich istnienia ${ }^{59}$. Następnie rozszerza swoje stanowisko, dodając, iż nie chodzi „o ten czy inny umysł”, lecz o „wszelkie umysły, takie czy inne”. Chce w ten sposób przeciwstawić się poglądowi, według którego istnienie przysługuje ideom jedynie wtedy, gdy jakiś konkretny podmiot (duch) je postrzega, że znikają one w przerwach w spostrzeganiu albo że są migotliwie stwarzane i unicestwia$n e^{60}$. Ostatecznie konieczny związek idei z umysłem ma polegać na ich zasadniczej poznawalności oraz zależności od Boga.

Bóg jest sprawcą idei, ich przyczyną ontologiczną, jako że idee pozbawione są mocy działania. Dla Berkeleya „przyczyna” to czynna siła wytwarzająca, gdy tymczasem ciała zmysłowe są całkowicie bierne, choć mobilne i podatne na zmianę. Owe „bierne rzeczy” mogą podlegać jedynie działaniu aktywnej przyczyny. Co więcej, idee nie występują w chaotycznych sekwencjach, ,jak się zdarzy i przypadkowo”, lecz „w sposób stały i prawidłowy”. Ich harmonia i celowość są dowodem boskiej mocy sprawczej.

Bóg nie jest zegarmistrzem nieobecnym w świecie, lecz - jak sądzi Berkeley - w harmonii przyrody jest percypowana Jego doskonała moc ${ }^{61}$. Sama jednak relacja Boga do idei jest w pismach Berkeleya bardzo niejasno przedstawiona. $\mathrm{Z}$ jednej strony wydają się one niesamodzielne wobec Absolutu (umysłu boskiego), z drugiej zaś Bóg ma je wywoływać („wrażać”, dokonywać ich „wyrycia”) w duchach. Skłonny jestem interpretować stanowisko Berkeleya jako transcendentyzm teistyczny ${ }^{62}$. Przy takim ujęciu filozofia Berkeleya jest realizmem ${ }^{63}$, a Bóg jest gwarantem istnienia świata.

57 Ibidem, s. 235.

58 H. Elzenberg (op. cit., s. 47) w takim aktualnym postrzeganiu (nie postrzegalności) jako warunku istnienia idei widzi istotę filozofii Berkeleya, jego subiektywizm ontlogiczny.

59 G. Berkeley, Traktat o zasadach ..., s. 39.

${ }^{60}$ Ibidem, s. 67.

${ }^{61}$ Idem, Trzy dialogi..., s. 229-230; idem, Traktat o zasadach..., s. 73.

62 Przez transcendentyzm rozumiem pogląd przypisujący światu istnienie nie autonomiczne, lecz samodzielne wobec podmiotu, w przypadku Berkeleya - podmiotu boskiego. Zob. J.J. Jadacki, Spór o granice poznania, Warszawa 1985, s. 71.

${ }_{63}$ Zwolennicy realistycznej interpretacji Berkeleya to A.A. Luce (The Dialectic of Immaterialism; Berkeley's Immaterialism) oraz F.J.E. Woodbridge (op. cit., s. 308-328). 


\section{UWAGI KOŃCOWE}

W zakończeniu chciałbym zwrócić uwagę na istotne dla mnie fragmenty rozważań filozofa, w których atakuje on ideę „rzeczy w sobie” oraz sam związek istnienia z „byciem dla podmiotu”.

Przyjrzyjmy się jeszcze raz stwierdzeniom Berkeleya ${ }^{64}$. Spróbujmy, pisze on, pojąc cokolwiek (dźwięk, kształt czy ruch) jako istniejące poza umysłem (niebędące „dla” umysłu). „Ależ - powiecie - na pewno nie ma nic łatwiejszego, niż na przykład wyobrazić sobie drzewa istniejące w parku albo książki w gabinecie, przy tym zaś nikogo, kto by je postrzegał"65. Lecz, argumentuje, czyż nie jest to złudzenie spowodowane pominięciem postrzegającego podmiotu, który to właśnie sobie wyobraża?

Sądzę, iż trzeba przyznać Berkeleyowi rację w tym, iż nie sposób „pozbyć się" postrzegającego (myślącego, wyobrażającego sobie) podmiotu.

Lecz umysł, nie biorąc samego siebie pod uwagę [podkr. - C.M.], łudzi się myślą, iż może wyobrażać sobie i że sobie wyobraża ciała, które istnieją przezeń niepomyślane, czyli znajdują się poza nim, mimo że są one jednocześnie przezeń pomyślane lub w nim obecne. Odrobina uwagi ujawni każdemu prawdę i oczywistość tego, co powiedziałem $[\ldots]^{66}$.

Berkeley łączy więc istnienie czegoś, jak pisze A.A. Luce, ze zdolnością do ujęcia tego właśnie ${ }^{67}$ jako - chciałbym dodać - warunku sensownego mówienia o czymś.

Filozof antycypuje ważne stanowisko, rezygnujące z mówienia o świecie bez dodatku „dla”. Otwiera więc drogę poglądowi relacjonistycznemu, zakładającemu konieczność ograniczenia pola badań do relacji podmiot - przedmiot. Nie ma ono konsekwencji w postaci idealizmu subiektywnego, choć jest w nim zawarta możliwość rezygnacji z filozofowania w opcji obiektywistycznej.

\section{BIBLIOGRAFIA}

Ajdukiewicz K., Epistemologia i semiotyka, [w:] Język i poznanie, t. 2, Warszawa 1985.

Ayer A.J., Language, Truth and Logic, New York 1936.

Berkeley G., Traktat o zasadach poznania ludzkiego, Warszawa 1956.

Berkeley G., Trzy dialogi między Hylasem i Filonusem, Warszawa 1956.

Elzenberg H., Domniemany immanentyzm Berkeleya, [w:] I. Dąmbska (red.), Szkice filozoficzne. Romanowi Ingardenowi w darze, Warszawa 1964.

Guzzo A., Berkeley and "Things", [w:] W.E. Steinkraus (ed.), New Studies in Berkeley's Philosophy, New York 1966.

${ }^{64}$ G. Berkeley, Traktat o zasadach..., s. 50.

65 Ibidem.

66 Ibidem.

${ }^{67}$ A.A. Luce, Berkeley's New Priciple..., s. 7-9. 
Hempoliński M., U źródet filozofii zdrowego rozsądku, Warszawa 1966.

Hochfeldowa A., Kryzys teologii naturalnej: George Berkeley, „Archiwum Historii Filozofii i Myśli Społecznej" 1971, t. 17.

Ingarden R., Niektóre założenia idealizmu Berkeleya, [w:] Księga Pamiątkowa Polskiego Towarzystwa Filozoficznego, Lwów 1931.

Jadacki J.J., Spór o granice poznania, Warszawa 1985.

Kijaczko S., Miejsce i rola empirystycznej teorii poznania $w$ systemie filozofii immaterialistycznej Berkeleya, Lublin 1991 (niepublikowany doktorat, UMCS).

Kołakowski L., Husserl i poszukiwanie pewności, Warszawa 1991.

Luce A.A., Berkeley's Immaterialism, London 1950.

Luce A.A., Berkeley's New Principle Completed, [w:] E. Steinkraus (ed.), New Studies in Berkeley's Philosophy, New York 1967.

Luce A.A., The Dialectic of Immaterialism, London 1963.

Luce A.A., Jessop T.E. (eds.), The Works of George Berkeley, Bishop of Cloyne, Vol. 2, Lodon 1949. Moore G.E., The Refutation of Idealism, [w:] Philosophical Studies, London 1951.

Mundle C.W.K., Perception: Facts and Theories, Lodon 1971.

Rorty R., Identyczność ciała i umystu, [w:] Filozofia umystu, wyb. B. Chwedeńczuk, Warszawa 1995. Sillem E.A., George Berkeley and the Proofs for the Existence of Good, London 1957.

Tipton I.C., Berkeley's View of Spirit, [w:] W.E. Steinkraus (ed.), New Studies in Berkeley's Philosophy, New York 1962.

Whiton Calkins M. (ed.), Berkeley, Essays, Principles, Dialogues With Selections from Other Writings, New York 1929.

Woodbridge F.J.E., Berkeley's Realism, [w:] Studies in the History of Ideas, Vol. 1, Cambridge 1918.

\section{SUMMARY}

The article presents an attempt to point out that Berkeley's achievements, despite the alleged consensus, cannot be located in the area of subjective idealism. Regardless of the formulations of Berkeley himself, who was not semantically clear, one can maintain the thesis that the world did not lose its position of real being for him, only that the reality of this world was totally dependent on the activity of the divine being. The philosopher rightly pointed out the indispensability of subjective approaches to access to the world. Without a proper ontology for the idea, Berkeley was unable to "tear" the idea from the mind, but it meant "being for the mind".

Keywords: idea; ontology; idealism; God; realism; mind

\section{STRESZCZENIE}

W artykule przedstawiam próbę wskazania na to, iż dokonania Berkeleya, mimo rzekomego konsensusu, nie dają się umiejscowić w obszarze idealizmu subiektywnego. Niezależnie od sformułowań samego Berkeleya, który nie pozostawał klarowny semantycznie, daje się utrzymać tezę, iż świat nie utracił dla niego pozycji bytu realnego, tyle że realność tego świata całkowicie była uzależniona od aktywności bytu boskiego. Filozof słusznie zwrócił uwagę na nieodzowność podmiotowych ujęć w kwestii dostępu do świata. Nie mając odpowiedniej ontologii dla idei, Berkeley nie był w stanie „oderwać” idei od umysłu, lecz znaczyło to u niego „bycie dla umysłu”.

Słowa kluczowe: idea; ontologia; idealizm; Bóg; realizm; umysł 